\title{
Give Us Vision, Lest We Perish: Engaging Disability at the National Library of Jamaica
}

\author{
Abigail Henry, National Library of Jamaica, Jamaica \\ Nicole Prawl, National Library of Jamaica, Jamaica \\ Beverley Lashley, National Library of Jamaica, Jamaica
}

\begin{abstract}
The World Health Organization (WHO) estimated that $15 \%$ of the world's population has a disability (WHO, 2011, p. 8). In Jamaica, the 2014 Disabilities Act affirms that people with disabilities have the right to education and training to ensure their ability to effectively and equally be included in all aspects of national life. While the true figures are underreported, a 2011 census found that 487,677 Jamaicans experience hearing problems. Of that figure, 5,628 persons range from being deaf to significantly hearing impaired (Statistical Institute of Jamaica, 2011). As the keeper of the nation's knowledge, the National Library of Jamaica (NLJ) must be accessible to all members of the nation, regardless of disability or physical limitations. In April 2018, the NLJ embarked on an initiative to enhance engagement of people with disabilities through a sign language training initiative for staff. For this pilot project, 14 staff members from various departments participated in weekly sign language training sessions for a period of 12 weeks. This training series is part of a wider initiative to improve accessibility at the NLJ for both staff and patrons. With a workforce that includes employees with disabilities, the NLJ has been engaged in the work of improving inclusion and engagement of individuals with disabilities. This paper outlines the existing challenges facing a Jamaican government entity as it moves to improve inclusivity, ongoing programmes, and outreach efforts to improve information literacy. This is being accomplished through partnerships with organizations working within Jamaica's Deaf community and through plans for designing a new, inclusive, and purpose-built facility to house the national collection.
\end{abstract}

Keywords: accessibility; Caribbean; Jamaica; National Library of Jamaica; sign language

Publication Type: special section publication

\section{Introduction}

n Jamaica, Persons with Disabilities (PWDs) face cultural marginalization and discrimination stemming from the traditional understanding of disability as either the result of witchcraft (or obeah) or divine punishment for unjust acts committed either by the person or their family member(s) (Ricketts, 2010). This perception has led to the exclusion of PWDs from full participation in social life.

It is estimated that over 500,000 people live with disabilities of various kinds (Statistical Institute of Jamaica, 2013). It is difficult to speak conclusively on disability prevalence in Jamaica as disability statistics are generally collected by national census and government registry, which face significant limitations to providing an accurate representation of the population (Statistical

The International Journal of Information, Diversity, \& Inclusion, 3(4), 2019

ISSN 2574-3430, jps. library.utoronto.ca/index.php/ijidi/index

DOI: $10.33137 /$ ijidi.v3i4.32997 
Institute of Jamaica, 2013). The most recent national population census (held in 2011) found that 487,677 persons experience hearing problems. Out of that figure, 5,628 people range from being deaf to significantly hearing impaired (Statistical Institute of Jamaica, 2013). However, it is believed that a significant number of cases are underreported as indicated in official census reports (Statistical Institute of Jamaica, 2013).

PWDs are largely excluded from the workforce. Factors such as lack of training opportunities, discrimination, and inaccessible infrastructure (i.e., buildings, public spaces, etc.) create significant barriers to their economic participation due to an inability to find jobs (Ricketts, 2010). Today, most parish council offices and government ministries do not have accessible facilities or accommodations in place. For example, a 2018 study found that none of the parish councils reported having elevators in buildings with more than one level (Carby, Ferguson, Steele \& Maiyaki, 2018). Access to employment and information has been identified as major challenges for the deaf in Jamaica (Patrick, 2018; Ricketts, 2010).

The 2014 Disabilities Act recognizes a person with a disability as one "who has a long-term physical, mental, intellectual, or sensory impairment which may hinder his full and effective participation in society, on equal basis with other persons" (Government of Jamaica, 2014, p. 4). This act is the country's governing legislation and was developed out of the 2000 National Policy on Persons with Disabilities; Jamaica's first anti-discriminatory rights-based policy on disability. The legislation exists "to promote, protect and ensure the full and equal enjoyment by persons with disabilities, of privileges, interests, benefits and treatment, on equal basis with others" (2014, p. 1). This statement echoes the guiding principles of the United Nations' Convention on the Rights of Persons with Disabilities (which Jamaica has ratified) and reflects an issue that has been well expressed by the World Health Organization: that disability is "not just a health problem. It is a complex phenomenon, reflecting the interaction between features of a person's body and features of the society in which he or she lives" (World Health Organization, 2019).

This emphasis on interaction affirms the rights of PWDs and places the onus on national bodies to ensure accessibility and inclusivity as they engage PWDs on an equal basis as others. Recognizing this, the NLJ endeavours to be accessible to all members of the nation, regardless of disability or physical limitations. In April 2018, the NLJ embarked on an initiative to enhance engagement of people with disabilities through a Jamaican Sign Language training initiative for staff. Under this pilot project, 14 staff members from various departments participated in weekly sign language training sessions for a period of 12 weeks. This training series is part of a wider initiative to improve accessibility at the NLJ for both staff and patrons. With a workforce that includes PWDs, the NLJ has engaged in the work of improving inclusion and engagement of people with disabilities.

As a reflective piece, this paper does not claim a methodology in the traditional sense and makes no attempts to draw conclusive arguments. Rather, the authors aim to highlight the ongoing efforts of the library while outlining the existing challenges facing a Jamaican government entity as it moves to improve inclusivity and bolster its contribution to national development. "Human rights are a discursive process, not a static set of prescriptive values" (Meekosha \& Soldatic, 2011, p. 1387). In the Caribbean, this process is ongoing and research on the subject is limited. Much remains to be done towards achieving the vision of an inclusive society. The NLJ aims to do its part through partnerships with organizations working within Jamaica's Deaf community and through plans for designing a new, inclusive, and purpose-built facility to house the national

The International Journal of Information, Diversity, \& Inclusion, 3(4), 2019

ISSN 2574-3430, jps.library.utoronto.ca/index.php/ijidi/index

DOI: $10.33137 /$ ijidi.v3i4.32997 
collection.

\section{Accessibility and Inclusiveness at the National Library of Jamaica}

The NLJ was established in 1979 to be the focal point for a national information and documentation system. The NLJ is the largest national library in the Caribbean region and the only such body in the English-speaking Caribbean "which fits the profile of a true national library" as defined by UNESCO (Peltier-Davis, 2011, p.3). The 2010 National Library of Jamaica Act makes explicit reference to accessibility, as section 5-1(L) outlines the function to "make the collection and facilities of the National Library accessible to the physically challenged" (Government of Jamaica, 2010 p.6). Additionally, in light of the mandate "to develop and promote national standards for the operation of libraries and the processing and delivery of information" (p. 5), it is incumbent upon the NLJ to lead the way in sensitizing and promoting interest in improving accessibility and engagement with individuals of varied abilities.

The NLJ has positioned itself at the forefront of regional efforts, such as the Caribbean Digital Audio Collection (CDAC), a pilot project to test the processes and structures needed to develop, produce, and deliver accessible Digital Talking Books (DTBs) for the Blind and print-disabled. ${ }^{1}$ This project established a framework for the development of a Caribbean Digital Audio Collection for the blind and visually impaired in Jamaica. The NLJ was designated as the coordinating entity for this effort to strengthen capacities in Jamaica and provide a model for the creation and distribution of digital audio collections, which can be adapted to other Caribbean territories.

\section{Sign Language Training Initiative at NLJ}

The sign language training initiative which began in 2018 is part of the ongoing effort to improve inclusivity at the NLJ. The staging of distinct projects in the past indicates that this has been an ongoing concern of which the organization has sought to address in various ways. An existing arrangement to employ individuals from the Danny Williams School for the Deaf is a marker of the NLJ's commitment to accessibility. The arrangement is long-standing but informal. The NLJ is in the process of formalizing the partnership with the School for the Deaf. It was, however, through assistance from the Jamaica Association for the Deaf (JAD), that the services of a sign language instructor/interpreter were secured to lead a 12-week long Introduction to Sign Language training programme for NLJ staff.

From an organizational point of view, by laying a framework for improved skills and knowledge transfer, the 2018 sign language initiative provided the continued opportunity to recruit deaf officers with the unique skillset necessary for working in the Preservation and Conservation Department. Through this initiative, the authors hoped to improve visibility of the NLJ with a view to position the organization as open to partnerships with corporate entities and NonGovernment Organizations (NGOs) engaged in promoting inclusion of PWDs.

The authors anticipated improved staff moral and a heightened feeling of engagement, particularly for our current deaf employee, Mr. Christopher Valentine. It was our hope that this would translate to improved performance and productivity while facilitating enhanced efficiency on the part of Mr. Valentine.

The 2018 Sign Language Training Initiative was intended to serve the following functions:

The International Journal of Information, Diversity, \& Inclusion, 3(4), 2019

ISSN 2574-3430, jps.library.utoronto.ca/index.php/ijidi/index

DOI: $10.33137 /$ ijidi.v3i4.32997 
- to facilitate improved communication in the workplace and ensure social inclusion of deaf patrons and employees

- to support the Government of Jamaica in its thrust to ensure PWDs are given the same opportunities as their counterparts without disabilities

- to enhance the overall communication competencies of NLJ staff and facilitate learning and development without discrimination

\section{Reflections on the NLJ Sign Language Training Initiative - The Process}

The success and sustainability of any workplace initiative hinges on the abilities and commitment of staff and human resources personnel. The staff of the NLJ was receptive to the programme and demonstrated interest in participating. Nicole Prawl, Manager of Preservation and Conservation and Mr. Valentine's direct supervisor, shares her reflections on the sign language training initiative below:

The NLJ has a history of employing PWDs, specifically those who are deaf or hearing impaired. These individuals have completed a programme at the Danny Williams School for the Deaf (which is run by Jamaica Association for the Deaf) in basic book binding and pamphlet box building techniques. Further on-the-job training is provided by the NLJ. These PWDs have generally worked in the Preservation and Conservation Department of the NLJ. The activities of the department include preservation work with various materials, such as paper, film, and microfilm. While the arrangement has not been made formal, records show that the Preservation unit has always included a member of staff who is deaf.

Mr. Christopher Valentine has been employed at the NLJ for over 10 years and is currently the only remaining deaf person on staff as all others have retired. Mr. Valentine came from JAD with special binding skills and a talent for building protective enclosures such as pamphlet boxes and canisters. He has greatly improved in book binding with the help of his team members of the Preservation and Conservation Department. Team members would try to communicate with Mr. Valentine by writing down instructions and demonstrating work that was to be done. In the past, we had the benefit of multiple deaf employees, some of which were more senior and could assist with training those who were new. However, these individuals retired shortly after Mr. Valentine's arrival. Communicating with Mr. Valentine was challenging at times as no member of staff had sufficient knowledge of sign language. Those who knew a little sign language were taught by one of the deaf retirees and the knowledge obtained was limited. Another way to communicate with Christopher was through writing notes to him, but even this came with its own set of problems as he often misunderstood what was being asked of him.

The challenges were expressed to the NLJ's human resources manager and the decision was taken to secure the services of a professional sign language interpreter in order to communicate important matters to Mr. Valentine. The interpreter made periodic visits to the office and Mr. Valentine and I visited the interpreter's office to facilitate discussions. I remember that in one of these meetings, Christopher expressed that he did not have anyone to talk with at work. He would be animated

The International Journal of Information, Diversity, \& Inclusion, 3(4), 2019

ISSN 2574-3430, jps.library.utoronto.ca/index.php/ijidi/index

DOI: $10.33137 /$ ijidi.v3i4.32997 
in these discussions and had a lot to express.

It became clear that there was a need for members of staff to gain basic sign language training in order to better accommodate this member of staff. Personally, I was interested in learning to sign. I wanted to communicate with Christopher not only on a professional level but to be able to have light-hearted conversations with him as colleagues.

\section{Selection of Participants}

It was at this point that the NLJ embarked on a programme to engage staff in learning the basics of sign language. Created through collaboration with a professional sign language interpreter, the 12-week programme began in April 2018 and consisted of weekly two-hour classes. Fourteen members of staff, including three employees from the Preservation and Conservation Department participated. Among the group were library assistants (who routinely interact with the general public and library patrons), as well the programme's director, a senior librarian, and a representative from the Human Resources Department.

The process of learning sign language was, at first, a little intimidating due to the depth of the information we were learning. However, Mr. Valentine was very willing to help us along. He sat in on classes and got a chance to interact with other staff members, in some cases, for the first time. We also had an excellent, deaf tutor who could read lips well. Over the course of 12 weeks, the team participated in, at times, challenging sessions. In the end, the biggest reward for us was learning to communicate in a more effective way with our colleague. Doing so has created major improvements for the Preservation and Conservation Department as we are now able to communicate, albeit at a basic level, with Mr. Valentine on work and non-work matters. We can now have those light-hearted conversations as colleagues, and he has been appreciative of the initiative taken by the NLJ. He expressed in one staff meeting that his boss now comes out of her office and speaks with him about non-work matters. He even admonished other people from the department about not joining the classes to learn sign language. While the length of the training programme could not produce professionals in sign language, the effort did succeed in creating a welcoming environment to learn how to communicate with those who are deaf.

\section{Practical Exposure}

The training culminated in a prize-giving presentation held during the time reserved for normal staff meetings. Over the course of 12 weeks, participants learned finger spelling and the Jamaican Sign Language alphabet, as well as several vocabulary categories, including: family, food, travel, and general knowledge. To show off their newfound abilities, participants signed along to Bob Marley's "One Love" and demonstrated how to sign common phrases, such as "please", "thank you", and "good morning". Participants reflected on the much-talked-about "Deaf Day" exercise in which participants were asked to compromise their ability to hear for 24 hours by stuffing cotton wool in their ears to block out sound. As participants struggled to carry out routine activities without the ability to hear as normal, the exercise fostered empathy and understanding.

It was particularly encouraging to have one of the instructors, Ms. Nicole Robertson, commend the NLJ for taking on the initiative. She encouraged the NLJ to continue to lead as a government agency in engaging members of the Deaf community. National Librarian, Beverley Lashley, was

The International Journal of Information, Diversity, \& Inclusion, 3(4), 2019

ISSN 2574-3430, jps.library.utoronto.ca/index.php/ijidi/index

DOI: $10.33137 /$ ijidi.v3i4.32997 
presented with a Certificate of Engagement in recognition of the NLJ's involvement with the pressing issue of inclusion and accessibility, as well as the active engagement of its own workforce. The NLJ continues to work with its Board of Management to secure funding and resources to carry on the training and expand outreach programming to Jamaica's Deaf community.

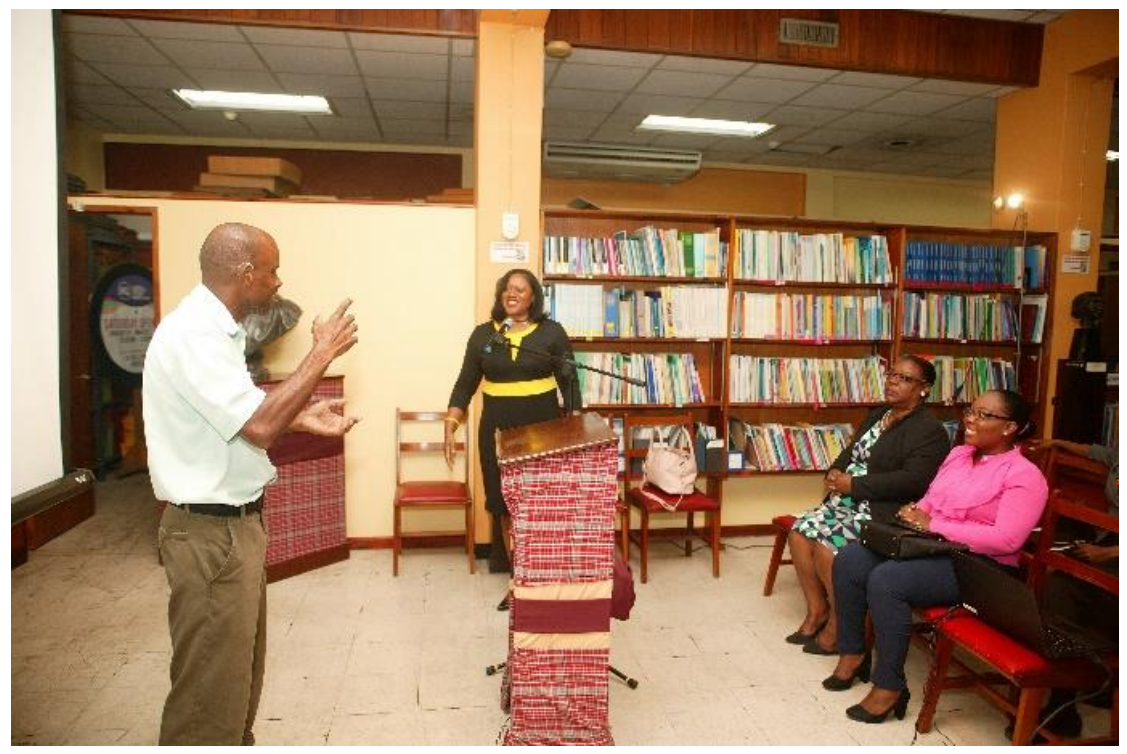

Figure 1. Christopher Valentine, restorer, expresses his feelings on the sign language training initiative. [Reproduced by permission]

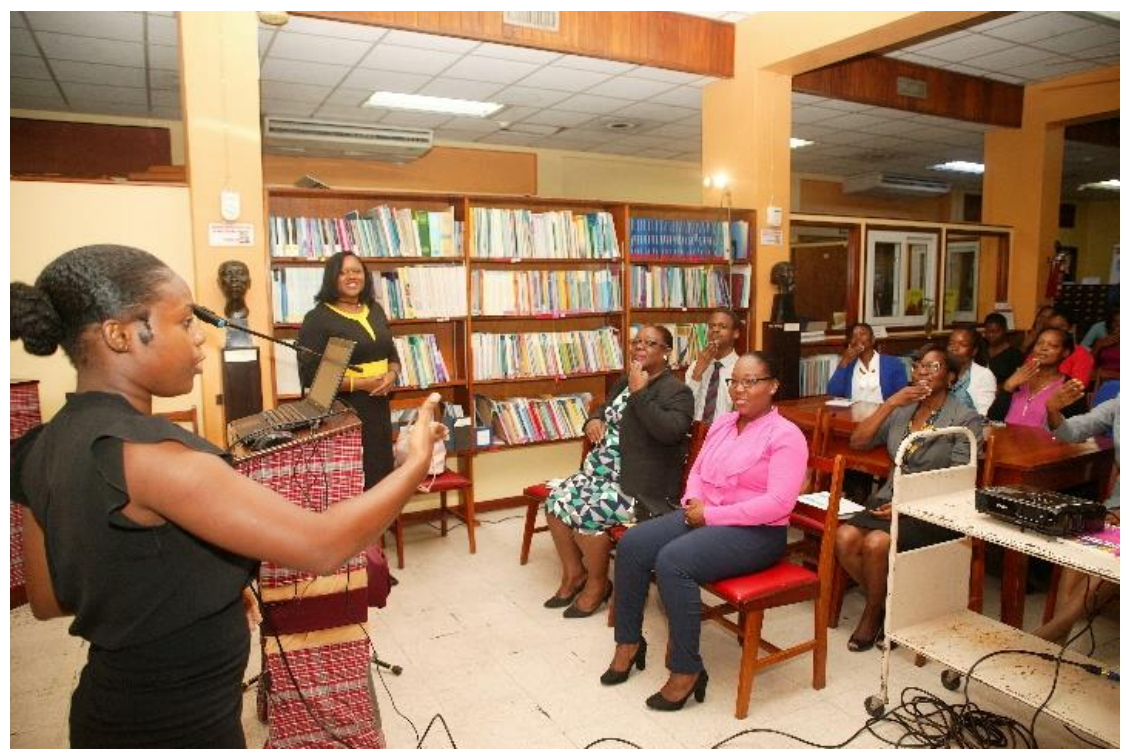

Figure 2. Kaffielee Moore teaches staff a few Jamaican Sign Language signs. [Reproduced by permission]

The International Journal of Information, Diversity, \& Inclusion, 3(4), 2019

ISSN 2574-3430, jps.library.utoronto.ca/index.php/ijidi/index

DOI: $10.33137 /$ ijidi.v3i4.32997 


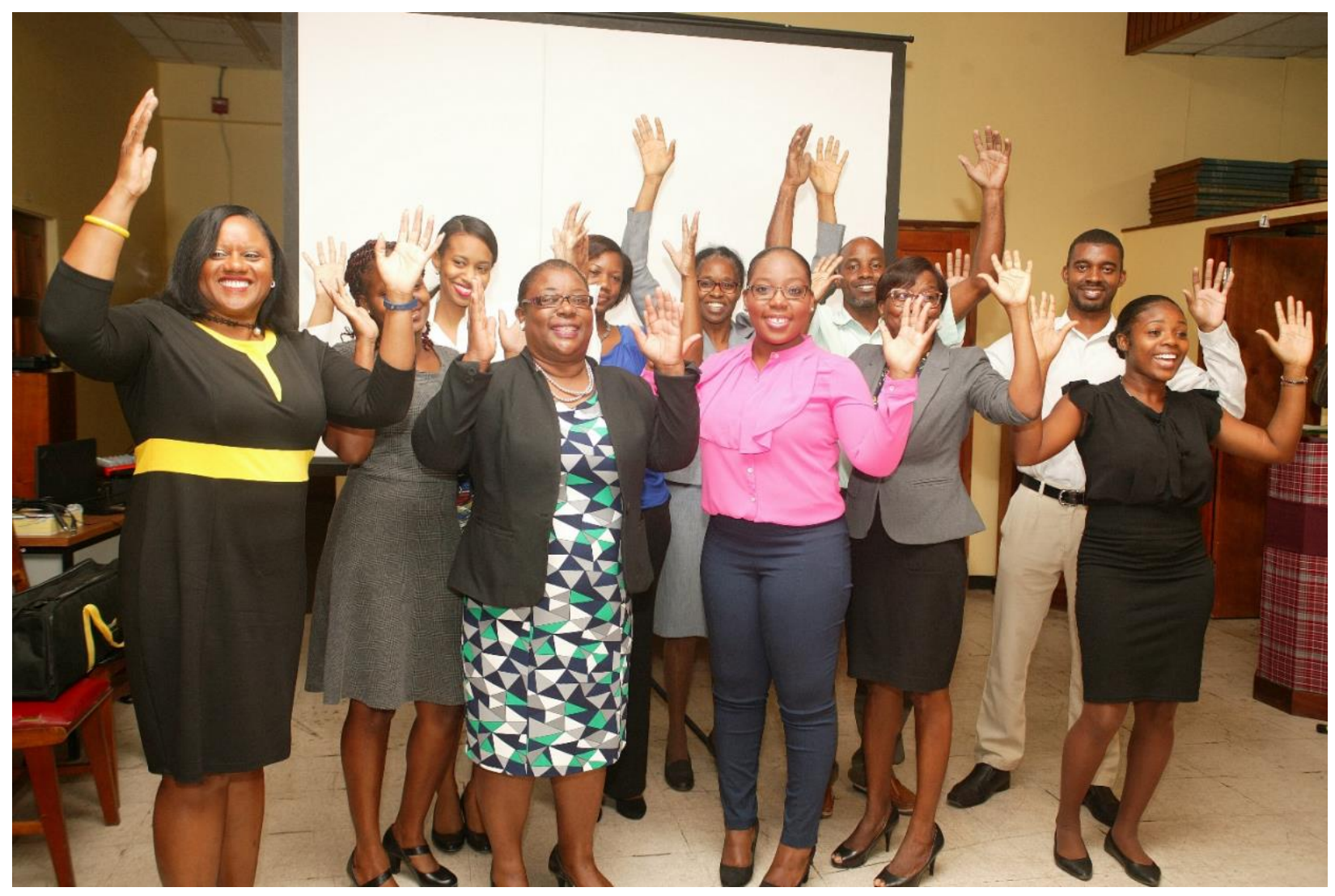

Figure 3. Participants of the 12-week introductory sign language course with instructors, Carol and Nicole Robertson. [Reproduced by permission]

\section{Challenges Facing Libraries in the $21^{\text {st }}$ Century - The NLJ Response}

Cheryl Ann Peltier-Davis identifies a major challenge facing libraries in the $21^{\text {st }}$ century: "how to harness and use information technology to provide core or traditional information services to a diverse clientele while simultaneously introducing new and innovative services" (2011, p.5). Recently, changes to the NLJ's website have included considerations for persons with perceptual disabilities. Some of the measures implemented include the enabling of alternative captions and narration for images, link description, enlarged clickable areas for users with mobility issues, and colour control for users with perceptual disabilities or colour blindness. Responsive web design is currently in effect on selected web pages with the intention of site-wide implementation. The use of subtitles/text transcripts and sign language interpretation for video content are elements that are being explored to improve accessibility of audiovisual resources. There is also a long-term plan to develop an accessibility guide for all NLJ sites and online collections.

Consistent outreach activity and awareness-raising is necessary to encourage the public to use the resources of the library. This is particularly so in a situation in which the NLJ has not previously catered to the needs of certain groups.

The International Journal of Information, Diversity, \& Inclusion, 3(4), 2019

ISSN 2574-3430, jps.library.utoronto.ca/index.php/ijidi/index

DOI: $10.33137 /$ ijidi.v3i4.32997 


\section{Accessibility and Inclusivity at the New Purpose-Built NLJ}

An obstacle to the NLJ engaging PWDs in a more meaningful way is the lack of accessible facilities. At the historic East Street location, the lack of elevator access, wheelchair ramps, accessible bathroom facilities, and insufficient parking pose considerable challenges for persons with limited mobility. Using technology, some solutions have been leveraged. For example, the creation of online collections and digitization of resources, such as the Index to Jamaican Poetry, Proverbs Collection, and Manuscripts Collection (this includes the archives of notable Jamaicans such as Louise Bennett Coverley and Anthony Winkler), have sought to improve access to library resources by allowing users to view materials remotely. However, the NLJ is unquestionably in need of a physical space commensurate to the functions and scope of a national library in the $21^{\text {st }}$ century.

These and other environmental barriers are to be addressed in the design of the new purposebuilt facility. The proposed building will have functional architecture, indicating that it is a library with its identity rooted in the society it is mandated to serve. The design objectives of the new NLJ prioritise accessibility and functionality with an emphasis on aesthetics, costeffectiveness, productivity, and security. The facility should cater to the needs of PWDs while incorporating safety and energy efficiency into the design. The entrance area to the library should provide ramps and wide-open spaces for ease of maneuvering. Elevators should have ample space to allow individuals who use wheelchairs freedom of movement. Other considerations will include automated door opener technology, the use of Braille on permanent signage, and lowered counters/service desks.

As the NLJ celebrates its $40^{\text {th }}$ anniversary in 2019 , the time is ripe for the realization of a facility that is poised to be a space of inclusion and engagement for all its users. We are pleased to reflect on past efforts as we plan strategic moves forward to fulfill our duty to all members of the nation, regardless of ability.

\section{Endnotes}

${ }^{1}$ More information on Digital Talking Books may be found here https://nlj.gov.jm/nationaldigital-library-services-for-the-blind-ndlsb-2-2

\section{References}

Carby, B., Ferguson, T., Steele, S., \& Maiyaki, Z. (2018). An exploration of inclusivity for persons with disabilities in disaster risk management planning at the national and local government levels in Jamaica. Disability Studies Quarterly, 38(4). Retrieved from http://dsq-sds.org/article/view/5776/5124

Government of Jamaica. (2014). The Disabilities Act, 2014 (Act 13 of 2014). Retrieved from https:/www.japarliament.gov.jm/attachments/341_The\%20Disabilities\%20bill\%202014\% 20No.13.pdf

The International Journal of Information, Diversity, \& Inclusion, 3(4), 2019

ISSN 2574-3430, jps.library.utoronto.ca/index.php/ijidi/index

DOI: $10.33137 /$ ijidi.v3i4.32997 
Government of Jamaica. (2010). National Library of Jamaica Act. In History of the National Library of Jamaica. Retrieved from https://nlj.gov.jm/wpcontent/uploads/2016/08/The-National-Library-of-Jamaica-Act-2010.pdf

Government of Jamaica. (2009). Vision 2030 Jamaica national development plan: Persons with disabilities draft sector plan. In National Planning Cycles. Retrieved from http://www.nationalplanningcycles.org/sites/default/files/planning_cycle_repository/ jamaica/microsoft_word_-_persons_with_disabilities_pdf.pdf

Hartman Reckord, E. (2018, May 28). Codes of practice to protect persons with disabilities. JIS News. Retrieved from https://jis.gov.jm/codes-of-practice-to-protect-persons-withdisabilities/

Meekosha, H., \& Soldatic, K. (2011). Human rights and the global South: The case of disability. Third World Quarterly, 32(8), 1383-1393.

National Library of Jamaica. (n.d.). Digital talking books. Retrieved from https://nlj.gov.jm/national-digital-library-services-for-the-blind-ndlsb-2-2

Patrick, J. (2018, August 15). Access denied: No provisions for deaf community. Jamaica Observer. Retrieved from http://www.jamaicaobserver.com/news/access-denied-noprovisions-for-deaf-community-at-recent_141442?profile=1373

Peltier-Davis, C. (2011). Overview of library services in the English-speaking Caribbean management, innovative services and resource sharing. [PDF file]. In World Library and Information Congress: 77th IFLA General Conference and Assembly 13-18 August 2011, San Juan, Puerto Rico. Retrieved from https://www.ifla.org/past-wlic/2011/81-davisen.pdf

Peltier-Davis, C., \& Renwick, S. (2007). Caribbean libraries in the 21st century: Changes, challenges, and choices. Medford, NJ: Information Today.

Ricketts, J. (2010). The making of Jamaica's 'national policy for persons with disabilities 2000': macro, meso and micro factors. [Abstract]. Disability and Society, 25(5), 551-564. https://doi.org/10.1080/09687599.2010.489300

Small, R., Myhill, W., Herring-Harrington, L. (2015). Developing accessible libraries and inclusive librarians in the 21st century: Examples from practice. Advances in Librarianship, 40, 73-88. https://doi.org/10.1108/S0065-283020150000040013

Statistical Institute of Jamaica. (2013). Population and housing census 2011: Disability indicators (Vol. 3). Government of Jamaica, Kingston.

World Health Organization. (2011). Summary world report on disability. In World Health Organization. Retrieved from www.who.int/disabilities/world_report/2011/report/en/

World Health Organization. (2019). Health topics: Disabilities. World Health Organization. Retrieved from www.who.int/topics/disabilities/en/

The International Journal of Information, Diversity, \& Inclusion, 3(4), 2019

ISSN 2574-3430, jps.library.utoronto.ca/index.php/ijidi/index

DOI: $10.33137 /$ ijidi.v3i4.32997 
Abigail Henry (abigail.henry@nlj.gov.jm) is the Director of Special Programmes at the National Library of Jamaica. She holds a BA in Media and Communication and Literatures in English from the University of the West Indies, Mona and a MA in Communication and Culture from York University, Toronto.

Nicole Prawl (nicole.prawl@nlj.gov.jm) has worked with the National Library of Jamaica for a number of years in different capacities. She is the Head of the Preservation \& Conservation Department. She holds a bachelor's degree in Library and Information Studies from the University of the West Indies, Mona and a Master of Science in Library and Information Studies with a concentration in archives from Simmons College, Boston, Massachusetts.

Beverley Lashley (beverley.lashley@nlj.gov.jm) is the National Librarian of the National Library of Jamaica. She has had a distinguished career in librarianship and business management spanning over 30 years with experience working in international contexts. She is a Fulbright Scholar and the recipient of the Caribbean Information Professional Award for 2011. Beverley is a passionate steward of the nation's documentary and literary treasures.

The International Journal of Information, Diversity, \& Inclusion, 3(4), 2019

ISSN 2574-3430, jps. library.utoronto.ca/index.php/ijidi/index

DOI: $10.33137 /$ ijidi.v3i4.32997 